\title{
TIME MANAGEMENT IN THE FAMILY ENVIRONMENT AND THE IMPACT OF TECHNOLOGY INVASION ON SOCIO-EMOTIONAL RELATIONSHIPS DURING THE COVID-19 PANDEMIC
}

\author{
Mauro Margalho Coutinho1 \\ University of Amazonia \\ mauro.margalho@unama.com \\ Sue Anne Collares Maestri de Oliveira ${ }^{2}$ \\ University of Amazonia \\ sueannecm@gmail.com \\ João Paulo Vasconcelos Mendonça Junior ${ }^{2}$ \\ University of Amazonia \\ joaopaulovmendoncajunior@gmail.com \\ Patrizia Raphaela Chermont Galiza ${ }^{3}$ \\ University of Amazonia \\ patchermont@gmail.com \\ Poliana Bentes de Almeida ${ }^{3}$ \\ University of Amazonia \\ polibentes@gmail.com
}

\begin{abstract}
Computer technologies have significantly evolved in their ways of interacting with humans. This article analyzes the effects of the large-scale invasion of ICTs in the lives of families in the Brazilian Amazon, assessing the impacts on their socio-emotional relationships. The analysis is based on two exploratory and predominantly qualitative studies conducted with families living in the Metropolitan Region of Belém, State of Pará, located in the Brazilian Amazon. One of the studies monitored 143 families daily during the period of confinement imposed by the COVID-19 pandemic in April 2020. The second study surveyed 71 families, obtaining data on socio-emotional aspects. The findings point out a conservative behavior toward technology, even in the face of a radical behavior change in social interactions.
\end{abstract}

Keywords: Invasion. Technology. Family. Relationship. Social Isolation.

\section{GESTÃO DO TEMPO NO AMBIENTE FAMILIAR E O IMPACTO DA INVASÃO DA TECNOLOGIA NAS RELAÇÕES SOCIOEMOCIONAIS DURANTE A PANDEMIA COVID- 19}

Resumo

As tecnologias de computador evoluíram significativamente em suas formas de interagir com os humanos. Este artigo analisa os efeitos da invasão em larga escala das TICs na vida de famílias na Amazônia brasileira, avaliando os impactos em suas relações socioemocionais. A análise é baseada em dois estudos exploratórios e predominantemente qualitativos realizados com famílias residentes na Região Metropolitana de Belém, Estado do Pará, localizada na Amazônia brasileira. Um dos estudos acompanhou 143 famílias diariamente durante o período de confinamento imposto pela pandemia COVID-19 em abril de 2020. O segundo estudo pesquisou 71 famílias, obtendo dados sobre aspectos socioemocionais. Os resultados apontam para um comportamento conservador em relação à tecnologia, mesmo diante de uma mudança radical de comportamento nas interações sociais.

Palavras-Chave: Invasão. Tecnologia. Familia. Relação. Isolamento Social.

\footnotetext{
1 Full Professor of the Graduate Program in Administration (PPAD) and of the Program on Knowledge Management for Social and Environmental Development (PPGC). University of Amazonia (UNAMA).

2 MSc students of the Graduate Program in Administration (PPAD), University of Amazonia (UNAMA).

3 MSc students of the Program on Knowledge Management for social and Environmental Development (PPGC), University of Amazonia (UNAMA).
} 


\section{INTRODUCTION}

Technological innovations such as the Internet have facilitated human life in numerous segments. Conceived in 1969, the Internet was a small network with a well-defined goal of connecting computers. The emergence of smartphones and mobile connectivity in 1994 made the Internet a global infrastructure connecting computers and, most of all, connecting people. We are currently moving towards a new conceptual model, idealized from the premise of a ubiquitous, pervasive environment, capable of interweaving anything: the so-called Internet of Things (IoT) (MAGRANI, 2018). In line with this new scenario, the term hyperconnectivity coined to describe individuals' availability to communicate anytime, anywhere - is currently in vogue. It entails a new scope of the Internet with ongoing research and testing on connectivity models known as Interplanetary Internet, in preparation for when humankind colonizes space (ALHILAL; BRAUD; HUI, 2018). This scenario of wide connectivity has transformed the routine of many families, especially in 2020, due to a phenomenon that has affected the whole world: the COVID-19 pandemic.

Data from the research TIC Kids Online Brasil (2018), coordinated by the Regional Center for Studies on the Development of the Information Society (Cetic.br) reflects this new era of global connectivity. The study shows that $88 \%$ of young Brazilians (9 to 17 years old) are regular Internet users (i.e., access the Internet every day). This percentage has been periodically monitored, showing an average growth of $6.83 \%$ per year. For those who access the Internet more than once a day, a variable that began to be monitored only in 2015 by Brazilian Internet Steering Committee (CGI.br), the average annual increase is $2.33 \%$ (Figure 1). In times of crisis, like the one between the end of 2019 and 2020, triggered by the COVID-19 pandemic, these numbers tend to grow substantially due to social distancing measures such as confinement and teleworking. Consolidated data on March 23, 2020, based on measurements made at the largest Internet exchange points in the world, registered a peak of 11 Terabits per second, which indicates an increase of about $60 \%$ in comparison with the previous year (CGI.BR, 2020). 
Figure 1 - Increase in Internet access by young people aged 9 to 17 in Brazil.

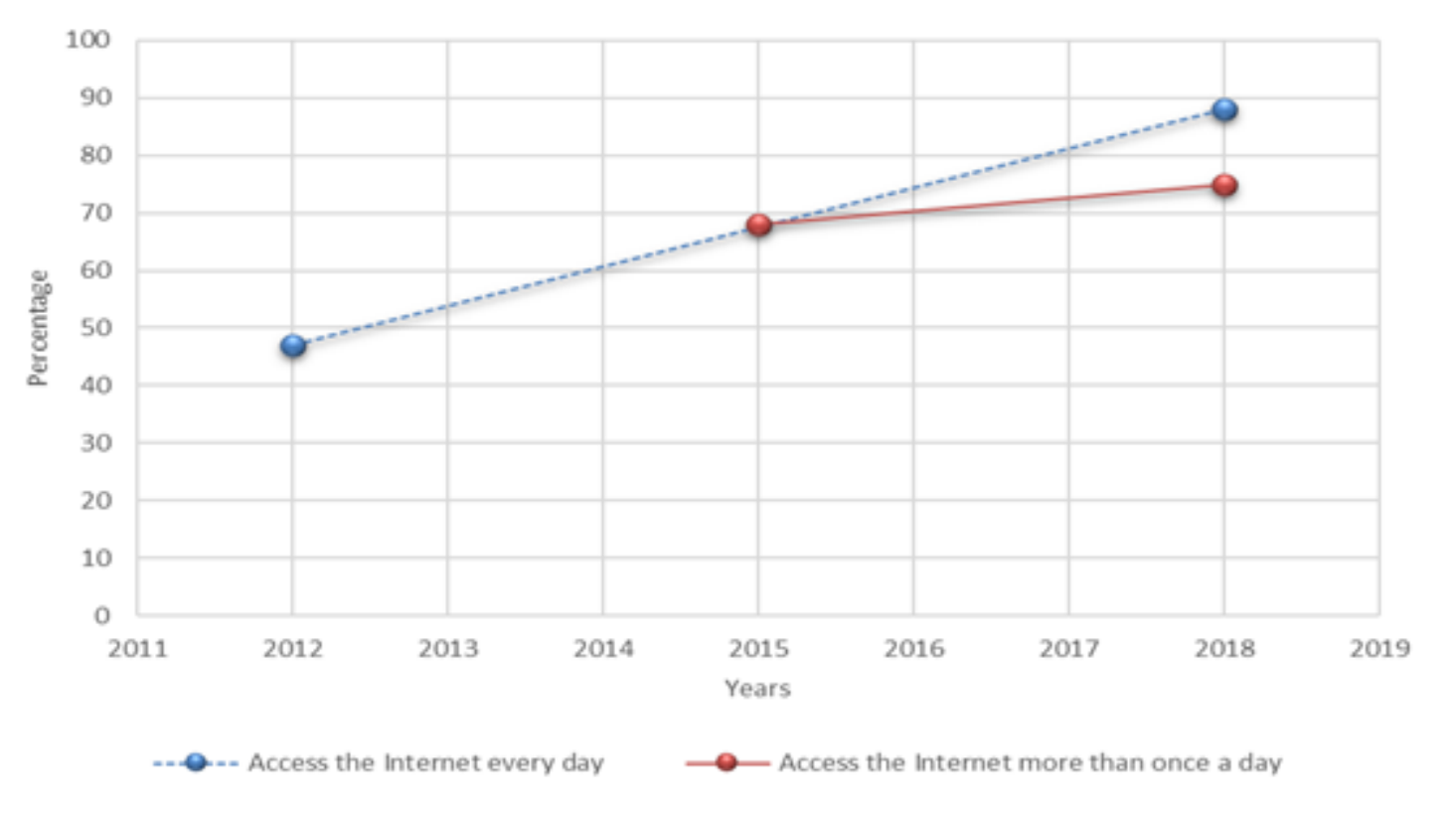

Source: TIC KIDS Online, 2018.

One of the consequences of this technological increase is the ubiquity of the Internet in homes, directly affecting the more traditional form of "face to face" dialogue, which often ends up being replaced by social media applications that serve as intermediaries of this process. This finding has been dividing scholars concerning its benefit or harm in terms of coexistence relationships within homes. Whenever technology enters people's lives in a disruptive $^{4}$ way, it provokes a reaction from society. It is worth remembering that, when the telephone started to become popular in homes at the beginning of the twentieth century, many feared that it would break the old practice of visiting family and friends. However, others argued that it would bring a privileged channel for access to information among family members (AYUSO, 2015). Arias et al. (2017) show that $85.8 \%$ of families think that the use of Information and Communication Technologies (ICTs) is very important. The aspects that most concern parents are related to the risk of dependence or abuse of ICTs, sexual harassment, interaction with strangers, fraud, and access to inappropriate content (ENCINAS; MOLL; FUENTES, 2015).

Regardless of the quality of the technology made available, it is clear that the increase in the use of technological resources in homes is a process with no return. The first months of

\footnotetext{
${ }^{4}$ Disruptive refers to something completely different from traditional models in a specific segment.
} 
2020 shed light on this phenomenon since, due to the enormous potential of contagion by the SARS-CoV-2, ICTs have proven to be the only option for safe social coexistence. This article investigates how families in the city of Belém, State of Pará, located in the Brazilian Amazon, have perceived and managed the impact of technology invasion in homes, including during the COVID-19 pandemic. It will address aspects considered positive, such as bringing families together when they live in different homes, and questionable aspects, such as weakening family bonds when the family lives together but spends more time using ICTs.

\section{METHODOLOGY}

The analysis presented in this article was based on two exploratory studies using convenience sampling. They were conducted in the Metropolitan Region of Belém (MRB), located in the state of Pará, in the Brazilian Amazon. The city of Belém is the largest municipality of the MRB, counting on an estimated population of almost 1.5 million people in an area of approximately $1,060 \mathrm{~km}^{2}$. Data from the last census conducted by the Brazilian Institute of Geography and Statistics (IBGE, 2019), showed a schooling rate of $96.1 \%$ among children aged 6 to 14 years old in Belém. The first study (S1) was carried out a few months before the adoption of social distancing measures in the MRB. The purpose was to investigate different aspects of the participants' dedication to family. Quantitative data was collected using a survey completed by 71 families. The study used a corpus built from information collected in seven interviews with professionals in the areas of social work, psychopedagogy, and psychology. In addition, Atlas TI and Iramuteq software were used to support qualitative analysis.

The second study analyzed in this article, (S2), involved 143 families residing in the MRB. The families were monitored daily through forms sent at the end of each day from April 5-19, 2020, in the midst of the crisis experienced by the COVID-19 pandemic. The forms collected data on socio-emotional issues, aspects related to the experience of being confined, and the use of ICTs. Table 1 shows the profile of participants in the two studies S1 and $\mathrm{S} 2$. 
Table 1 - Profile of Respondents of Studies S1 and S2

\begin{tabular}{|c|c|c|c|}
\hline & Item & Description & Respondents (\%) \\
\hline \multirow{21}{*}{1} & \multirow{5}{*}{ Age } & Between 18 and 25 years & 5.6 \\
\hline & & Between 26 and 35 years & 12.7 \\
\hline & & Between 36 and 45 years & 35.2 \\
\hline & & Between 46 and 55 years & 43.7 \\
\hline & & Over 56 years old & 2.8 \\
\hline & \multirow{2}{*}{ Sex } & Male & 21.1 \\
\hline & & Female & 78.9 \\
\hline & \multirow{7}{*}{ Education } & Incomplete Basic Education & 1.4 \\
\hline & & Incomplete High School & 2.8 \\
\hline & & Complete High School & 5.6 \\
\hline & & Incomplete Higher Education & 8.5 \\
\hline & & Complete Higher Education & 19.7 \\
\hline & & Post Graduate Latu-Sensu (specialization) & 33.8 \\
\hline & & Post Graduate Stricto-Sensu (Master or PhD) & 28.2 \\
\hline & \multirow{7}{*}{ Marital status } & Single & 21.1 \\
\hline & & Married & 67.6 \\
\hline & & Separated but live in the same residence & 1.4 \\
\hline & & Separated but DO NOT live in the same & \\
\hline & & residence & 4.2 \\
\hline & & Stable union & 4.2 \\
\hline & & Other & 1.5 \\
\hline \multirow{7}{*}{2} & \multirow{5}{*}{ Age } & Between 18 and 24 years & 14 \\
\hline & & Between 25 and 34 years & 30 \\
\hline & & Between 35 and 44 years & 42 \\
\hline & & Between 45 and 54 years & 10 \\
\hline & & Over 55 years old & 4 \\
\hline & \multirow{2}{*}{ Sex } & Male & 28 \\
\hline & & Female & 72 \\
\hline
\end{tabular}

Source: The authors, 2021.

P2P \& INOVAÇÃO, Rio de Janeiro, v. 7, Ed. Especial, p. 186-207, jan. 2021. 


\section{ANALYSIS AND DISCUSSION}

\subsection{LARGE-SCALE TECHNOLOGY INVASION}

In 2020, the measures to increase social distancing undertaken in many countries increased the domestic use of technology on a global scale. This scenario required an adaptation of great proportions in the routine of Brazilian families. Education, formerly taught in person, began to be taught online. In many cases, schools have adopted synchronous tools, where the student connects to a platform on agreed days and times, and the teacher is available to interact in real time. Also, many parents had to change their labor routine and adopted teleworking to minimize the risk of contagion. While at home, families relieved, even if temporarily, domestic workers (an activity common in Brazil). This further burdened the family with domestic chores, especially mothers, consequently reducing the time dedicated to improving interpersonal relationships in the family. Technology started to be explored as the only, truly safe, channel for socio-emotional bonds between families and friends that did not share the same physical space.

The two-weeks monitoring carried out in S2 helped to understand some behavioral aspects of families, which supported the analysis of several issues addressed in this article.

Initially, the analysis sought to assess how the evolution of the participants' experience in confinement was, particularly exploring the use of technology, and their perceptions and socio-emotional needs. Figure 2, relates the evolution of the number of deaths registered in the MRB with the behavior of the research participants, showing that, initially, families reduced face-to-face interactions, limiting the number of visitors to their homes. After a while, face-to-face interaction grew again, demonstrating the difficulties of undertaking social distancing measures, even in the face of the possibility of infection. It should be emphasized that local authorities widely reported the figures about the pandemic's evolution. The death toll continued to rise on a large scale. The growth of deaths was exponential: on April 19, 2020, date of the last data collected from families participating in the S2, the number of victims was 34. In about a fortnight, on May 05, 2020, 375 deaths were registered, i.e., an increase of more than 1,000\% (SESPA, 2020). Another worrying aspect about the pandemic's evolution and its severity was the high number of underreported deaths related to COVID-19, since there was shortage of test kits to confirm the contamination of the deceased persons. A study carried out by the portal Saúde of Editora Abril (ZIEGLER, 2020), shows an estimate of deaths fourteen times higher than the official numbers. 
Figure 2 - Progress of official deaths from COVID-19 vs. Visitors participants received at home

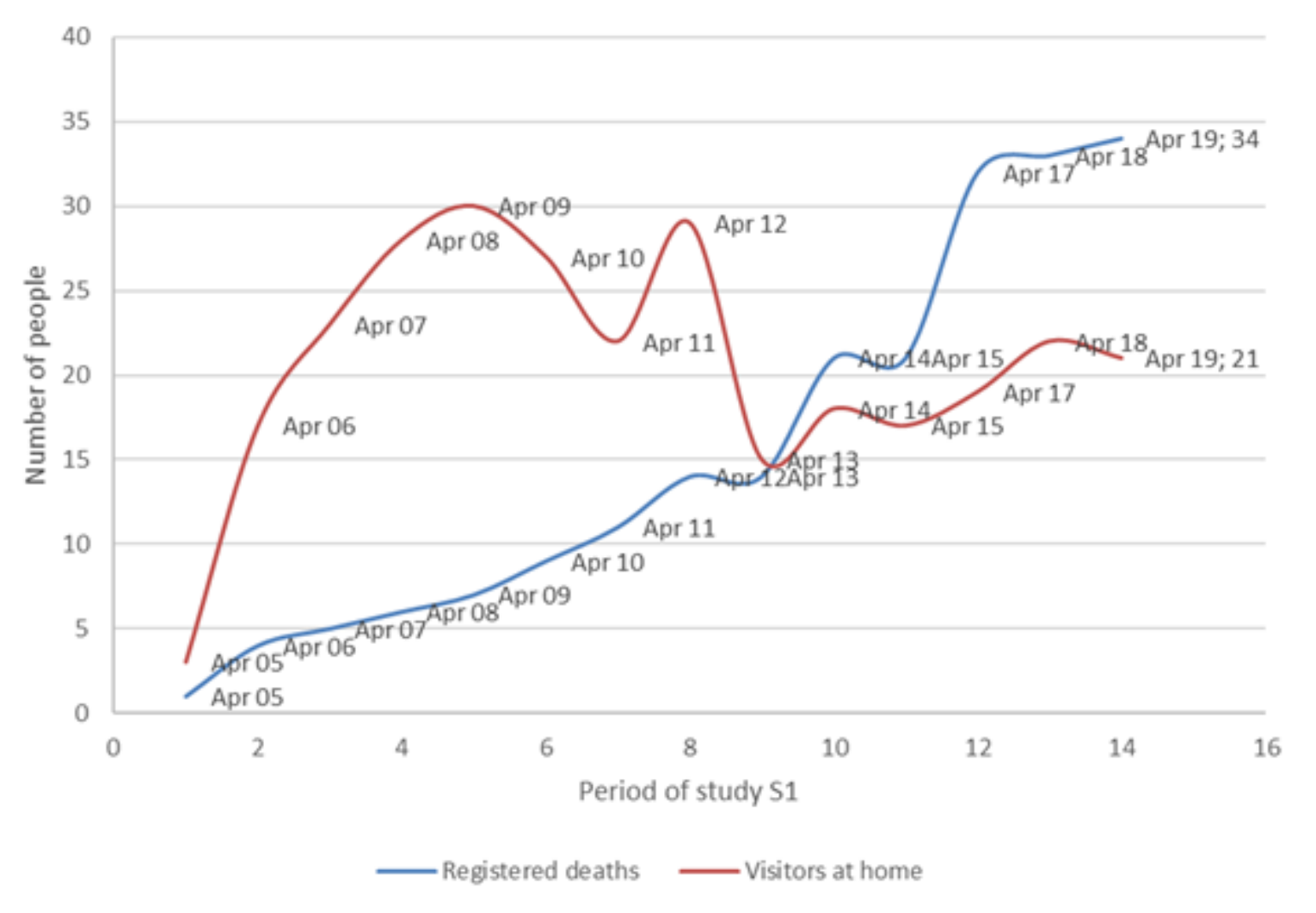

Source: Deaths (SESPA, 2020) and data collected in the study S2

The participant families were asked for their perspective on how much social distancing was being respected by the residents living close by. Figure 3 shows that the majority of residents in the participants' vicinity did not respect social distancing measures, even though it was strongly recommended by health authorities. This variable is important because it serves as a parameter to gauge how much the families participating in the research saw themselves as an exception in this process. 
INOVAÇÃO

Figure 3 - Perception of neighbors' compliance with social distancing measures

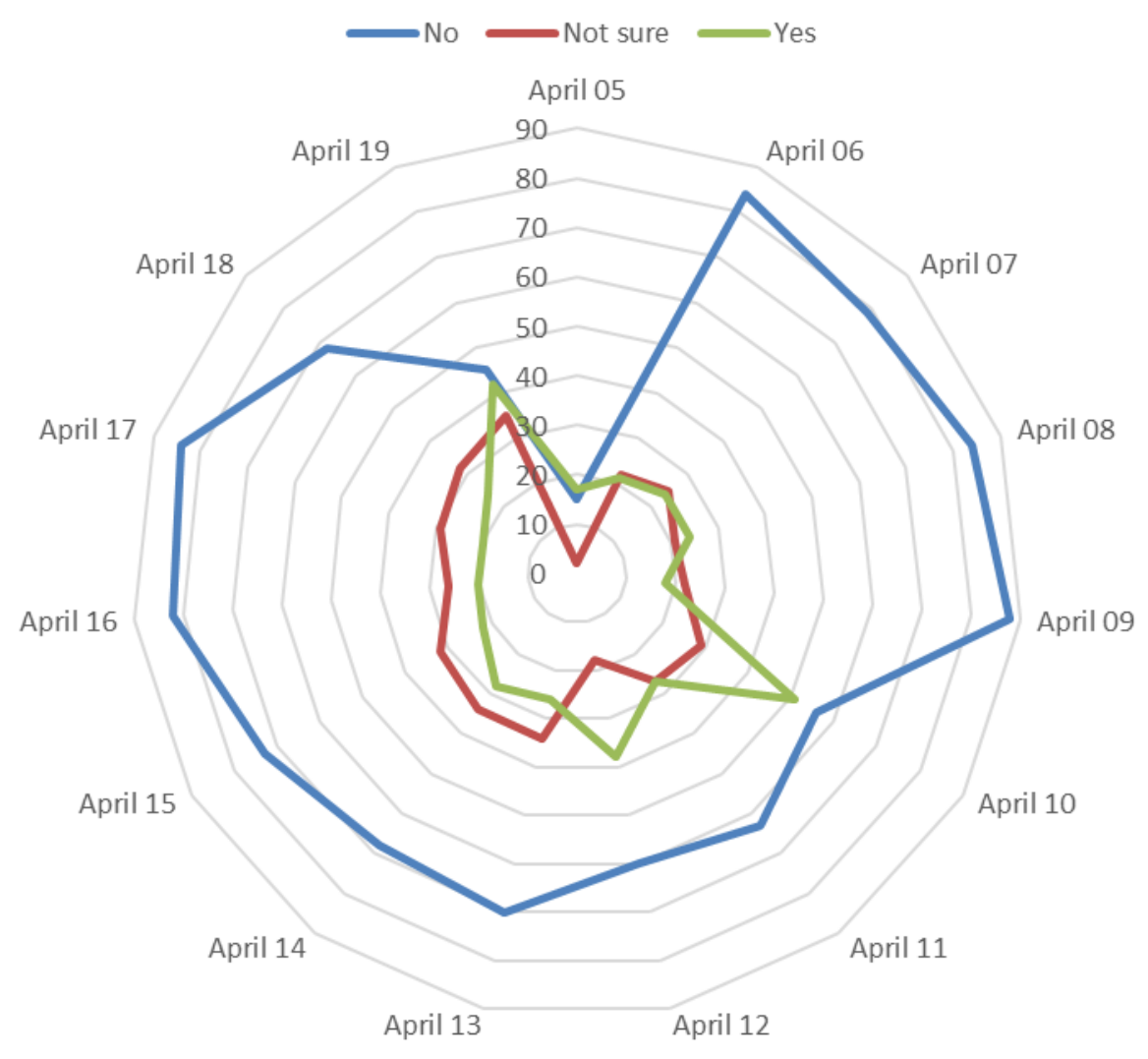

Source: The authors, 2021

Another aspect analyzed was the use of technology during confinement. The objective was to investigate the level of families' involvement with digital communication tools. Figure 4 shows that most families used social media while confined. However, the study did not show changes in this behavior during the period of S2. Those who were using social media to communicate at the beginning of the confinement maintained the behavior, and those that did not use social media did not start using it, which suggests that adherence to technology may not occur suddenly, even in adverse situations. 
Figure 4 - Use of social media during the research period

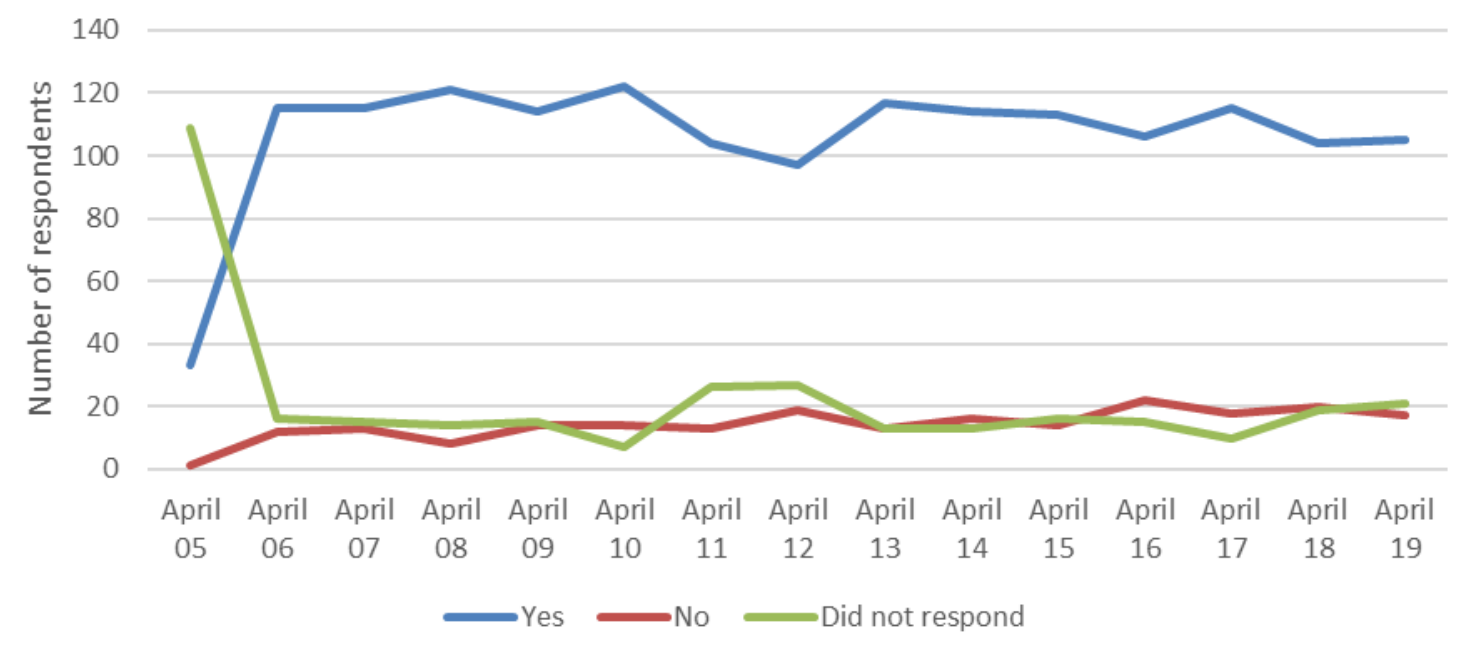

Source: The authors, 2021

When asked if there was a greater emotional closeness among family members during the research period, despite the majority having answered affirmatively every day, there is a tendency for this closeness to fall over time, as shown in Figure 5.

Figure 5 - Closeness among family members

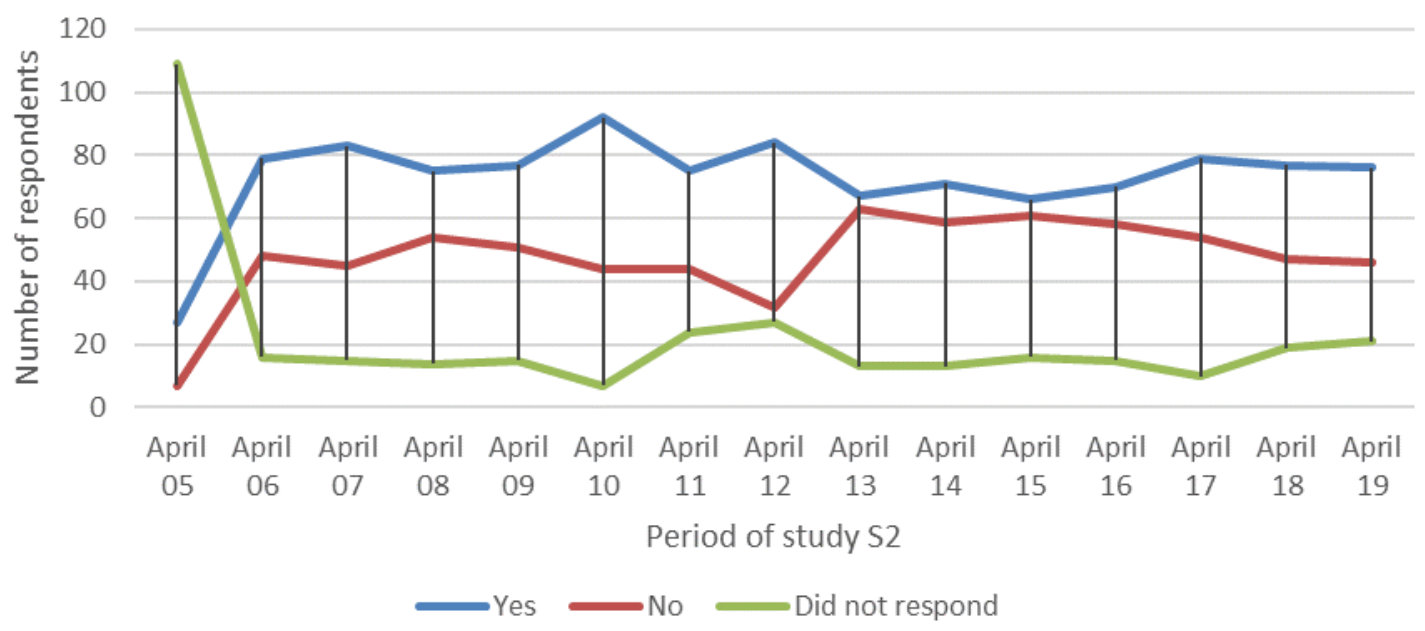

Source: The authors, 2021

Figure 6, shows the perception of need for affection. Most respondents reported not to have noticed such factor in their family members, except over weekends. Numerous factors can explain this phenomenon, but it cannot be ruled out that this may be a reflection of a possible lack of time by the respondent to acknowledge the family members' behavior. This would be plausible since, during the week, most of the research participants are working 
(telework), and, therefore, they can dedicate more attention to family members only on weekends.

Figure 6 - Perception of need for affection

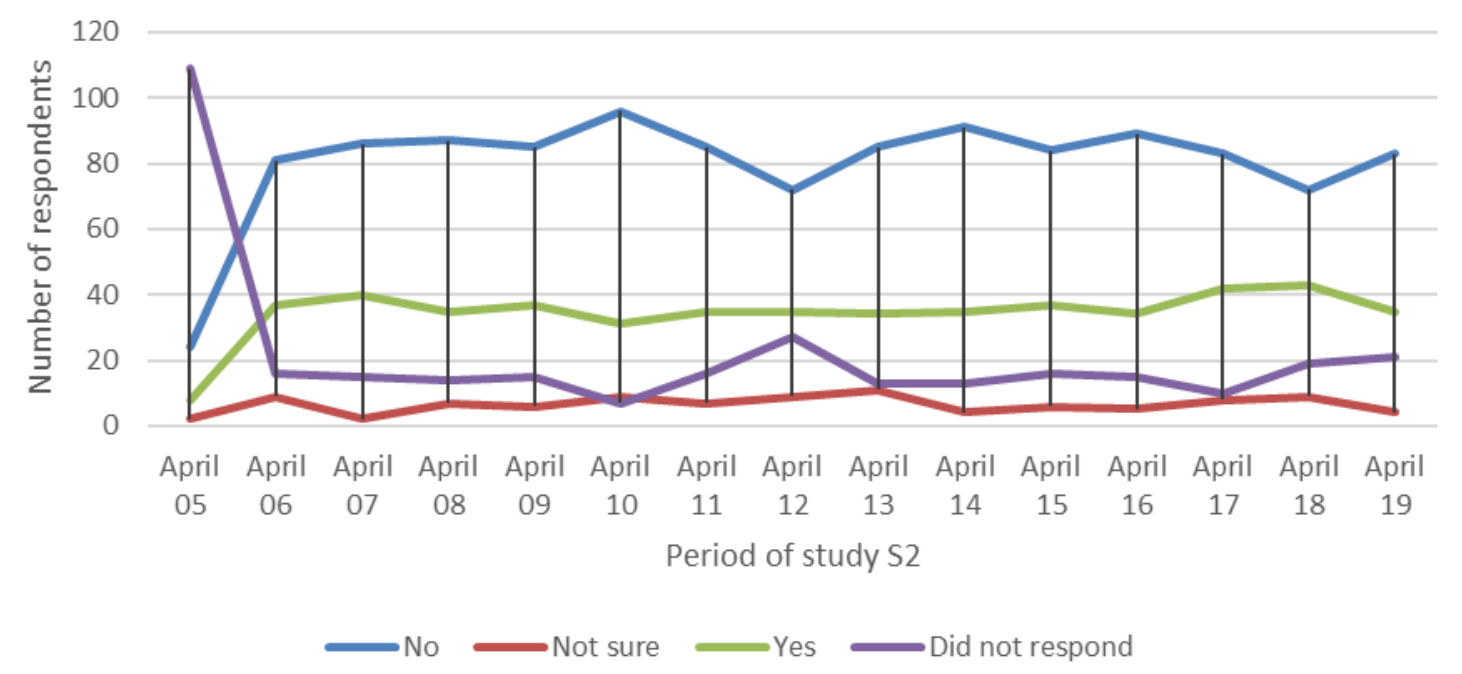

Source: The authors, 2021

Even though the research is based on a small population, it is possible to infer that families in the state of Pará tend to be cautious when it comes to change behavior, especially with regard to the adoption of technology. This argument is reinforced when considering that even in a pandemic, people show a very traditional behavior toward culture and technology. One explanation for this phenomenon may be related to each family's experience regarding benefits and harm linked to the concept of technology, as discussed below, which influence the perception of technological novelties.

\subsection{BENEFITS AND HARM OF TECHNOLOGY IN THE FAMILY}

Within a systemic view, the family can be considered as a dynamic system. Dias (2011), subdivides this system into four subsystems. The marital subsystem appears when two adults come together in an interdependent and complementary relationship. The parent-child refers to the arrival of the first child, which modifies the system (followed by other children). The parental subsystem is primarily responsible for education, socialization, and protection at all levels. Finally, the sibling subsystem refers to the relationship among the children in the family. Coyne et al (2014), bases their representation of the family on the family systems theory (BRODERICK, 1993), suggesting that the use of media in the family context could strengthen the bonds among its members, encouraging interaction between children and 
parents and facilitating important discussions in the family. However, when delegating excessive responsibilities, inherent to the family, to technology, there is a risk of compromising affective ties.

An experiment developed by the Argentine company Sherpas, supported by the UNICEF and implemented on Facebook, created a project that allows interactivity, in real time, among young people and a fictional (virtual) character called Fabi Grossi. The proposal was to create an interactivity channel to discuss sexting, or the leakage of intimate images without consent. A robot (roBOT software) interacts with young people and is equipped with artificial intelligence (AI) resources, to simulate interaction with a human. The initiative guides young people in an environment that is part of their daily lives. However, criticism has been made arguing whether it would be better for young people to talk to someone in their family, reinforcing parental ties, instead of investing energy talking to a machine, even if this contact is a strategy to encourage youngsters to talk at an early stage of dealing with the issue of sexting5. Data from TIC Kids online Brasil (2018), show that 537,000 people have completed the seven stages proposed in the contact with the virtual character Fabi Grossi on Facebook. Of these, 300,000 responded to a form after contact with the BOT, the majority (75\%) were young women aged between 13 and 25 years old, and almost half of them confirmed to have had some experience of sexting. Despite the positive aspects of the initiative $-90 \%$ of the young people participating declared to have learned a lot about the theme and on how to proceed when involved in this kind of situation - the focus in this article is to discuss whether it is reasonable to attribute such a responsibility to a BOT. It should be emphasized that, in this experience, young people are subject to the guidance of an AI in a continuous learning process, programmed by human beings, and potentially hackable. Therefore, the AI can be programmed based on a specific ideology. As it happens in the learning process observed with a child, a BOT can autonomously learn through training.

Emotionally vulnerable people are prone to be influenced, and the case of the blue whale challenge is an example of the importance of supporting them. In the blue whale challenge, participants were asked to perform fifty challenges sent by a curator, the last of which was to take their own life (BARRETO JUNIOR; LIMA, 2017). Lowering family surveillance, leaving young people to seek help for their problems on the Internet, depending

5 Several times during the interaction with the AI, the participant is strongly encouraged to talk to someone about what happened. 
on the source of that help, can bring unpredictable consequences. The discussion in this article refers to finding a balance in the use of technology, emphasizing the families' mediating role.

The analysis of technology use in the family system should always consider the family context. In her doctoral dissertation, Bianchini (2018), addresses the beneficial use of technology by so-called borderless families, a term used to designate families with members who live geographically distantly. In these cases, technology brings family closeness and strong ties. However, even in this context, one can perceive a change in behavior over time. The use of on-demand services where people interact when, where, and how they wish (social media platforms such as Facebook and WhatsApp) is increasingly growing, to the detriment of online tools based on co-presence (Zoom, Microsoft Teams, Blackboard, and Google Meet). In this second group, interaction is synchronous or simultaneous, supported by audio and video, and allowing more significant behavioral observations such as looks, gestures, positions, and verbal statements. Co-presence platforms have been used in educational activities during the pandemic by private universities and schools operating in the MRB. As for social media platforms, it is noteworthy the use of paralinguistic communication (emoticon). The term came from the concatenation of the words emotion and icon. Emoticons are represented graphically through a sequence of typographic characters or reduced images (PAIVA, 2016). However, even though the interaction is considered a multimodal system, many perceptions of the "face-to-face" modality cannot be fully captured in this format.

During the pandemic, many doctors in the MRB (VILANOVA, 2020), as well as in Italy (SARAIVA, 2020), used synchronous audio and video transmission platforms to promote a final meeting between terminal COVID-19 patients and their families.

\subsection{TECHNOLOGY AND FAMILY CLOSENESS - IN PERSON INTERACTION}

Study S1 aimed to analyze the internal aspects of family relationships in the MRB. One of these aspects was family presence at mealtimes. Research by the Harvard Graduate School of Education on family meals together found that many family ties and traditions are created during meals (THE FAMILY DINNER PROJECT, 2020). In terms of academic and emotional benefits, for example, lower rates of drug use and depression, more resilience, broader vocabulary, greater reading ability and, in general, better grades at school, stand out. Considering the difficulties modern families face to meet for meals during the week, the research participants were asked to inform, through a 5-point Likert scale, how often they usually have meals together over the weekend. The majority (70.4\%) answered that they often 
have meals with the family on weekends, followed by those who occasionally do (25.5\%). Only $4.2 \%$ claimed to rarely $(2.8 \%)$ or never $(1.4 \%)$ eat meals together. Thus, the participant families have maintained this habit despite the invasion of technology in their daily lives.

Another aspect questioned was related to the average time dedicated exclusively to the family. Most of the respondents (28.2\%) reported dedicating between 5 and 10 hours a week exclusively to the family, while (22.5\%) dedicate more than 10 hours (Figure 7).

Figure 7 - Average time dedicated to the family

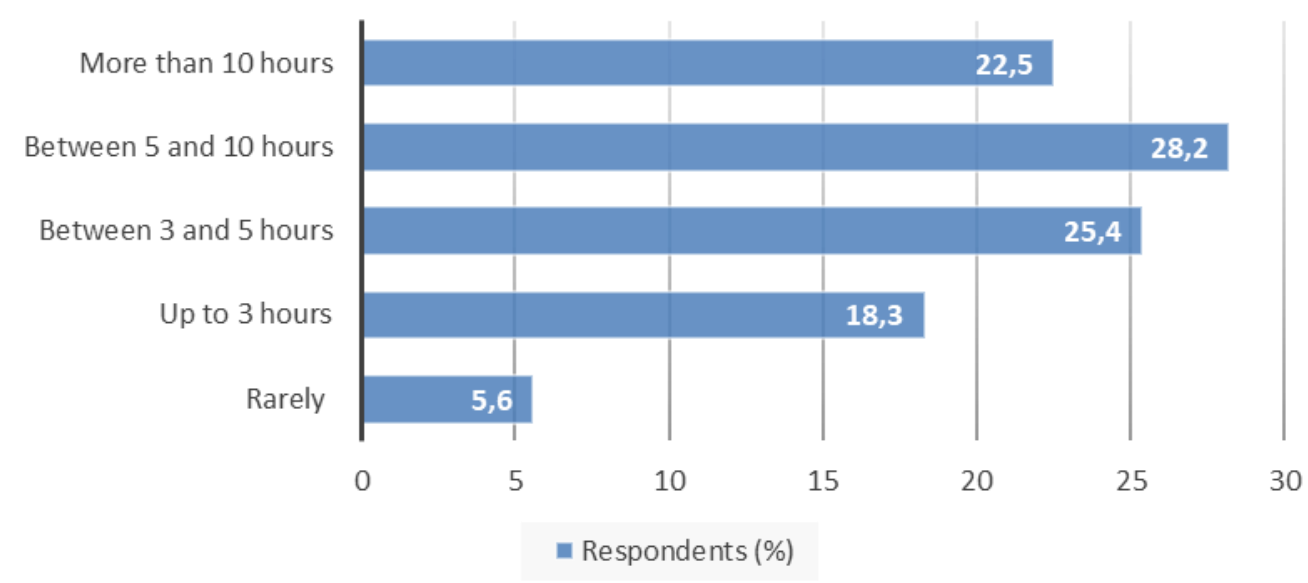

Source: The authors, 2021

When asked whether they think emerging technologies have affected family closeness using a 5-point Likert scale, most of the group (33.3\%) was unsure. In this item, $15.3 \%$ said that it significantly affects closeness and $12.5 \%$ said that it does not, as shown in Figure 8 . The study S2, however, denotes a conservative trend regarding this topic. 
Figure 8 - Technologies affect family closeness

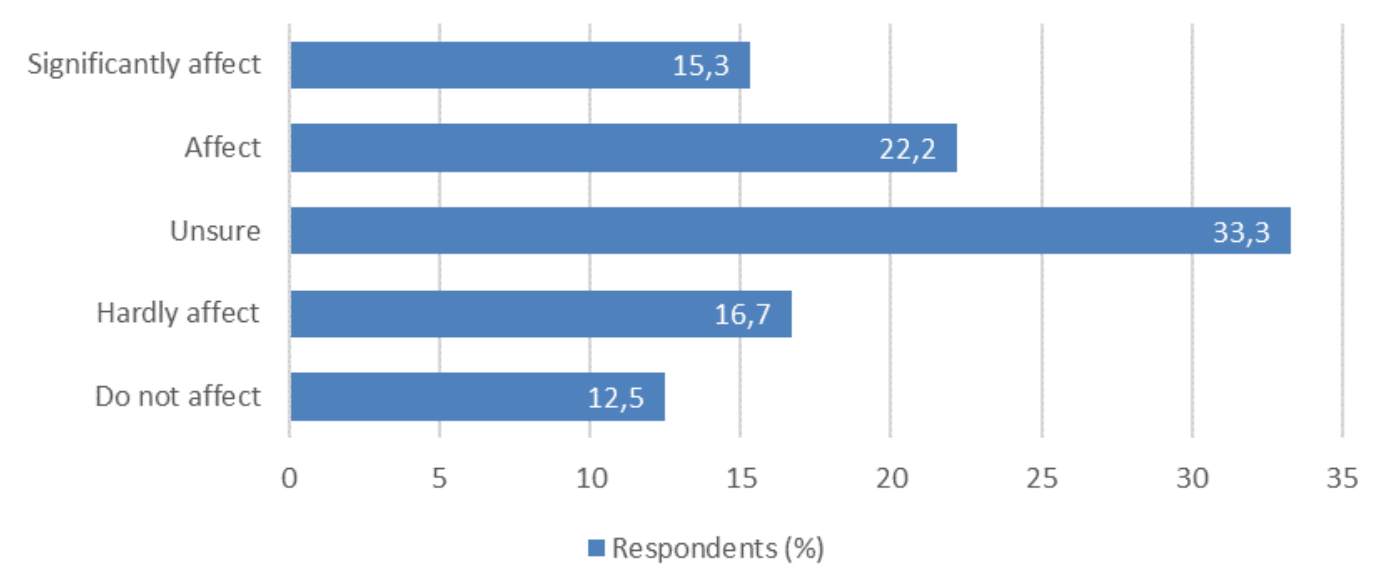

Source: The authors, 2021

Concerning the quality of time spent together, study S1 asked about the behavior of the family toward the use of technology during vacation periods. In this regard, $60.6 \%$ of the respondents said that they partially disconnect from technology during vacations, to experience more proximity to the family. Others $(35.2 \%)$ do not disconnect, as they believe it is possible to experience proximity to the family without giving up technology. Only $4.2 \%$ said they disconnected completely to experience more proximity to the family. Therefore, the majority of the respondents did not consider technology a problem that compromises proximity and dedication to the family, being totally or partially compatible with leisure moments. The respondents informed that when they request their children to take a break from using some technological apparatus to enjoy a moment of more intensive family time, $47.7 \%$ said their children show little or no resistance in doing so. This number is close to that obtained when parents responded about their willingness to take a break from using technology to enjoy family time $(40.9 \%)$.

When asked if they had a specific room in the house where everyone frequently meets to watch TV or streaming, $91.5 \%$ of the respondents answered yes.

Study S1 also explored whether it was common for respondents to turn off their cell phones in more private places. To this question $76.1 \%$ answered no. This may be associated with the fact that $56.3 \%$ claimed to have the feeling of being with their children when using the cell phone corroborated by $84.5 \%$ having an instant messaging group exclusive to the family.

It is important to ensure that the feeling of closeness, caused by the ubiquitous connectivity, does not become a digital addiction, which is constantly associated with a 
primary disorder such as anxiety, panic, and social phobia (KING, 2013). Users with these characteristics, known as nomophobia, usually carry several devices with them for fear of being disconnected from the online world.

To analyze the problem from the perspective of professionals who work daily with issues of family relationships, study S1 carried out interviews with five social workers, one professional of psychopedagogy and one psychologist. In the similarity analysis, obtained from the responses of these professionals, it was possible to perceive the strong positive link established between family and technology.

Another issue addressed during the interviews was the possible dispersion of the families' attention due to the current moment of high connectivity. Interviewees were asked to reply through a 5-point Likert scale, if this practice could compromise the observation of symptoms such as depression, aggressiveness, or low school performance in children. Figure 9 shows that opinions are still divided, with the most part of interviewees unsure $(43 \%)$ whether there is a connection.

\section{Figure 9 - Dispersion due to high connectivity}

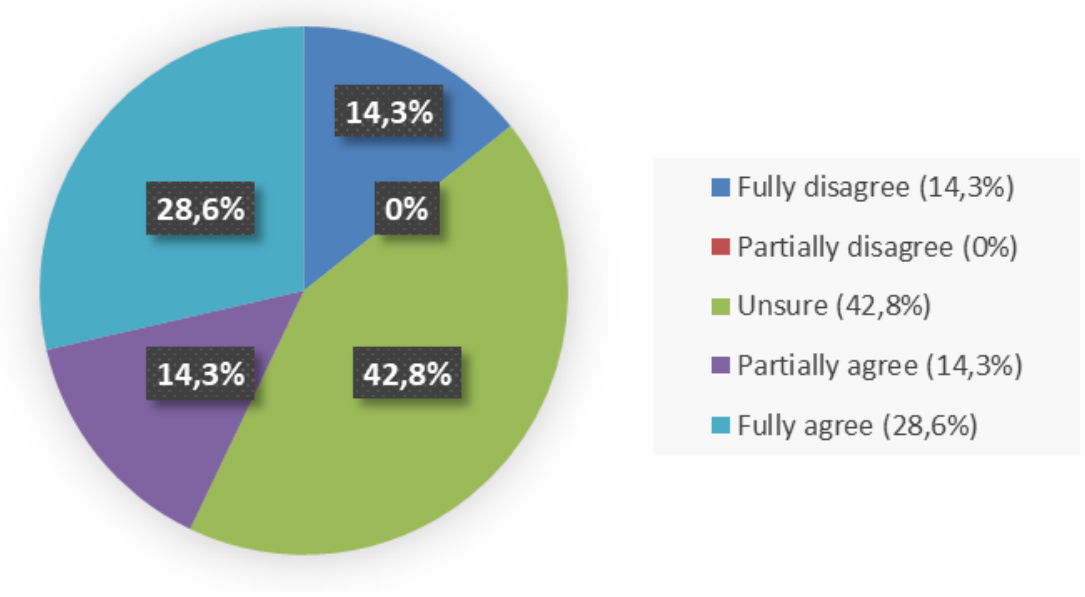

Source: The authors, 2021

Each column presented in Table 2 (Interviewee \#1, Interviewee \#2, etc) refers to one of the interviewed professionals, while each line represents an adopted coding. The GR variable, when presented in the columns, indicates the number of documents (citations) associated with that particular interviewee. For example, interviewee 1 , with GR $=4$, means that the codes mentioned in the lines of the table (Advice with digital influencers, negative aspects of technology, etc.) were extracted from four documents from the interviewee's speech. In the case of interviewee 2, the codes have been extracted from seven documents and so on. It is worth mentioning that in the same speech (document) the interviewee may have 
alluded to more than one code, which occurs in this specific research and justifies the fact that some GR values are lower than the number of codes. When related to the lines, below each code, the variable GR indicates the number of respondents who referred to that code. Table 2 shows the relationship between the seven items coded in Atlas TI from the interviews with professionals who participated in the research:1-Advice with digital influencers, 2-Negative aspects of technology, 3-Positive aspects of technology, 4-Form of interaction, 5-Quality family time, 6-Family meetings and 7-Moderate use of technology. It can be observed that the most cited codes refer to the positive and negative aspects of technology use, followed by the involvement with digital influencers. In the issues associated with digital influencers, there is concern among the interviewed professionals regarding the adoption of a bias on the subject that differs from the family values. This issue can trigger a family relationship crisis, since young people are highly influenced by fashion, to the detriment of traditions. Surprisingly, the quality of family time, a factor expected to be the most mentioned item, ranked last in the list of coded quotes from the interviews. This may be due to the fact that many consider it an obvious item, having been referred to only by the professional of psychopedagogy who made the following observation: "[...] the quality of time we spend with our family and friends is better than the quantity". 
Table 2 - Interview Code-Form Table

\begin{tabular}{|c|c|c|c|c|c|c|c|c|c|c|c|c|c|c|c|}
\hline \multirow[t]{2}{*}{ Code } & \multicolumn{2}{|c|}{$\begin{array}{c}\text { Interviewee } \\
\# 1 \\
\mathrm{Gr}=4\end{array}$} & \multicolumn{2}{|c|}{$\begin{array}{c}\text { Interviewee } \\
\# 2 \\
\mathrm{Gr}=7\end{array}$} & \multicolumn{2}{|c|}{$\begin{array}{c}\text { Interviewee } \\
\# \mathbf{3} \\
\mathrm{Gr}=\mathbf{3}\end{array}$} & \multicolumn{2}{|c|}{$\begin{array}{c}\text { Interviewee } \\
\# 4 \\
\mathrm{Gr}=6\end{array}$} & \multicolumn{2}{|c|}{$\begin{array}{c}\text { Interviewee } \\
\# 5 \\
\mathrm{Gr}=6\end{array}$} & \multicolumn{2}{|c|}{$\begin{array}{c}\text { Interviewee } \\
\# 6 \\
\mathrm{Gr}=4\end{array}$} & \multicolumn{2}{|c|}{$\begin{array}{c}\text { Interviewee } \\
\# 7 \\
\mathrm{Gr}=5\end{array}$} & \multirow[t]{2}{*}{ Total } \\
\hline & Abs & $\%$ & Abs & $\%$ & Abs & $\%$ & Abs & $\%$ & Abs & $\%$ & Abs & $\%$ & Abs & $\%$ & \\
\hline $\begin{array}{c}\text { Advice with } \\
\text { digital } \\
\text { influencers } \\
\text { Gr=7 }\end{array}$ & 1 & 16.56 & 1 & 14.29 & 1 & 25 & 1 & 12.5 & 1 & 14.29 & 1 & 20 & 1 & 20 & 7 \\
\hline $\begin{array}{c}\text { Negative } \\
\text { aspects of } \\
\text { technology } \\
\text { Gr=9 }\end{array}$ & 1 & 16.56 & 2 & 26.57 & & & 3 & 37.5 & 1 & 14.29 & 1 & 20 & 1 & 20 & 7 \\
\hline $\begin{array}{c}\text { Positive } \\
\text { aspects of } \\
\text { technology } \\
\mathrm{Gr}=9\end{array}$ & 1 & 16.56 & 1 & 14.29 & 2 & 50 & 1 & 12.5 & 2 & 28.57 & 2 & 40 & & & 7 \\
\hline $\begin{array}{c}\text { Form of } \\
\text { interaction } \\
\mathrm{Gr}=7\end{array}$ & 1 & 16.56 & 2 & 28.57 & & & 1 & 12.5 & 1 & 14.29 & 1 & 20 & 1 & 20 & 7 \\
\hline $\begin{array}{c}\text { Quality } \\
\text { family time } \\
\text { Gr=l }\end{array}$ & & & & & & & & & & & & & 1 & 20 & 1 \\
\hline $\begin{array}{c}\text { Family } \\
\text { meetings } \\
\mathrm{Gr}=4\end{array}$ & 1 & 16.56 & & & & & 1 & 12.5 & 1 & 14.29 & & & 1 & 20 & 4 \\
\hline $\begin{array}{c}\text { Moderate } \\
\text { use of } \\
\text { technology } \\
\text { Gr=5 }\end{array}$ & 1 & 16.56 & 1 & 14.29 & 1 & 100 & 1 & 12.5 & 1 & 14.29 & 5 & 100 & 5 & 100 & 42 \\
\hline
\end{tabular}

Source: The authors, 2021 
Table 3 - lists the main positive and negative aspects of the use of technology mentioned in the interviews.

Table 3 - Positive and negative aspects of technology use

“[...] technology is positive when it is used in moderation and doesn't interfere in family or social interactions [...]"

"[...] feasibility of communication and research, as well as ease in solving everyday situations, including within the family, including for issues related to security $[\ldots]^{\prime \prime}$

“[...] technology helps, approximates, offer range of information [...]"

Positive

"...Time must always be evaluated as a positive factor $[\ldots] "$

Aspects

"[...] family interaction in cases such as travel. Real-time communication and ease of information dissemination [...]"

"[...] it connects you with the world and with family, relatives, and friends [...]"

"[...] we use technology a lot to solve everyday problems [...]"

"[...] technology has been guiding families in the state of Pará with regard to access to globalization $[\ldots . . . "$

"[...] technology as a means of social interaction to strengthen family bonds [...]"

"[...] the influencer does not know the person and their particularities [...]"

"[...] distancing from family members even when living in the same home, often talking to each other through social media, consequently fragmenting feelings and bonds, causing fragility in family relationships [...]"

"[...] the modern method sometimes negatively influences family relationships $[\ldots]^{\prime}$

“[...] these technologies take over limits of time and become addictive, a

Negative Aspects dependence, changing the affective bonds into something virtual $[\ldots] "$
"[...] We're close, but not together, we're in the same space but in different worlds [...]"

"[...] what works for one person doesn't work for another [...]"

"[...] in addition to getting in the way of the family dynamic of dialogue that profits from the interaction of the group as a whole. It creates groups within the group $[\ldots]^{\prime}$

"[...] social and affective distancing within the family environment [...]"

"[...] conversation in the living space, eye to eye, healthy discussions are affected with the arrival of software in general $[\ldots]$ ”,

Source: The authors, 2021

P2P \& INOVAÇÃO, Rio de Janeiro, v. 7, Ed. Especial, p. 186-207, jan. 2021. 


\section{FINAL CONSIDERATIONS}

Although technology may have a role in the fragmentation of family time, it is not the only factor putting family relationships at risk. Other issues, from precarious work - for Montali (2013), this type of work affects family life since it promotes arrangements that compromise traditional hierarchy - to the change in habits due to the evolution of democratic principles, contribute to deteriorating family relationships. Notwithstanding, it is crucial to recognize that we are, personally, ultimately responsible for preserving our family lives. Parents often see their children's social isolation as a form of protection and ignore the risks involved in this process. In Japan, a phenomenon known as hikikomori has been studied that is growing and is already worrying many scholars. It is spontaneous social isolation motivated, mainly, by hyperconnectivity. This phenomenon, where young people live without even leaving their rooms, already affects $1.57 \%$ of the Japanese population (GENT, 2019). For several decades, parents were strict, demanding that the whole family be together during breakfast, lunch, and dinner (TEIXEIRA; FROES; ZAGO, 2006). This behavior was seen by the children as an example to be followed. Nowadays, parents' difficulties in maintaining the family's economic standard compromise the quantity and, often, the quality of family time. The analyses found that the radical changes in the way of living together experienced during the confinement imposed by the COVID-19 pandemic were not perceived as so radical, showing that there are other elements in family relationships than simply living under the same roof.

Technology needs to be considered as an aggregating agent and not as a substitute for face-to-face family relationships. It is important to recognize our responsibilities for our family relationships without demonizing technology as the only source of all problems faced in social interactions. The very use of technological resources, whether bringing entertainment during periods of social distancing or saying goodbye to loved ones, has given new meaning to technology in the face of different social contexts. These relationships need to be enhanced qualitatively since the time together is likely to reduce due to modern life. One of the ways to create family empowerment is to discuss family problems together in person. This practice will create incentives that minimize the search for third parties (in the case of the Internet, digital influencers) to solve problems, strengthening family bonds. It is worth reflecting on the phenomenon of parents who, overwhelmed by new technologies, feel like going back to 


\section{ARTIGO}

- INOVAÇÃo

the old days. It is important to create a stronger sense of belonging to the group based on trust and availability. 


\section{REFERENCES}

ALHILAL, A.; BRAUD, T.; HUI, P. The Sky is NOT the Limit Anymore: Future Architecture of the Interplanetary Internet. arXiv.org, 2018. Available at: https://arxiv.org/pdf/1810.01093.pdf. Access in: 13 Jan. 2020.

ARIAS, A. V. et al. How Does the Use of ICTs Affect Family Relationships? A Quantitative Approach. Global Journal of Health Science, v. 9, n. 10, 2017. Available at:

https://pdfs.semanticscholar.org/8a44/b3ce20aec6fdcd7691d06b505874be1b7cec.pdf. Access in: 20 Mar. 2020.

AYUSO, L. El impacto de las TIC en el cambio familiar en España. Revista Española de Sociología, n. 23, p. 73-93, 2015. Available at:

https://recyt.fecyt.es/index.php/res/article/view/65370/39668. Access in: 09 Mar. 2020.

BARRETO JUNIOR, I. F.; LIMA, M. A. Suicídio e o jogo da Baleia Azul analisados na perspectiva de Anomia de Émile Durkheim. Revista de Sociologia, Antropologia e Cultura Jurídica, v. 3, n. 1, p. 121-136, 2017. DOI 10.26668/IndexLawJournals/25260251/2017.v3i1.1836.

BIANCHINI, A. F. Famílias sem fronteiras: um estudo dos usos e apropriações de tecnologias de informação e comunicação por famílias com membros que vivem apartados. Tese (Doutorado em Comunicação Social) - Faculdade de Comunicação Social, Pontifícia Universidade Católica do Rio Grande do Sul, Rio Grande do Sul, 2018. Available at: http://repositorio.pucrs.br/dspace/bitstream/10923/12774/1/000489754-Texto\%2bCompleto0.pdf. Access in: 24 Jan. 2020.

BRODERICK, C. B. Understanding family process: Basics of family systems theory. Newbury Park, CA: SAGE, 1993.

CGI.BR. IX.br alcança marca de $10 \mathrm{~Tb} / \mathrm{s}$ de pico de tráfego Internet. Comitê gestor da Internet no Brasil. 19 mar. 2020, texto atualizado em 25 de março de 2020. São Paulo: CGI.br, 2020. Available at: https://www.cgi.br/noticia/releases/ix-br-alcanca-marca-de-10-tbs-de-pico-de-trafego-internet/. Access in: 17 Mar. 2020.

COYNE, S. et al . Media Time = Family Time: Positive Media Use in Families With Adolescents. Journal of Adolescent Research, v. 29, n. 5, p. 663-688, 2014.

DIAS, M. O. Um olhar sobre a família na perspectiva sistémica - o processo de comunicação no sistema familiar. Gestão e Desenvolvimento, n. 19, p. 139-156, 2011. Available at: https://repositorio.ucp.pt/handle/10400.14/9176. Access in: 23 Feb. 2020.

ENCINAS, F. L.; MOLL, A. R.; FUENTES, M. H. Guía para padres y educadores sobre el uso seguro de Internet, móviles y videojuegos. Madri: Fundación Gaudium. 2015.

Available at: https://www.ucm.es/data/cont/docs/39-2015-03-22-

Gu\%C3\%ADa\%20para\%20padres\%20y\%20educadores\%20sobre\%20el\%20uso\%20seguro\% 20de\%20Internet,\%20videojuegos\%20y\%20m\%C3\%B3viles.pdf. Access in: 12 Dec. 2019.

GENT, E. Quem são os hikikomori, os jovens japoneses que vivem sem sair de seus quartos. BBC News Brasil, 2019. Available at: https://www.bbc.com/portuguese/vert-fut-47441793. Access in: 30 Mar. 2020. 
IGBE. Brasil. Pará - Belém: Panorama. Available at: https://cidades.ibge.gov.br/brasil/pa/belem/panorama. Access in: 27 Feb. 2020.

KING, A. L. S. Nomophobia: Dependency on virtual environments or social phobia? Computers in Human Behavior, v. 29, p. 140-144, 2013. Available at: https://doi/10.1016/j.chb.2012.07.025. Access in: 27 Feb. 2020.

MAGRANI, E. A internet das coisas. Rio de Janeiro: FGV Editora, 2018. 192 p.

MONTALI, L. Rearranjos Familiares de Inserção, Precarização do Trabalho e Empobrecimento. Revista Brasileira de Estudos de População, v. 21, n. 2, p. 195-216, 2013. Available at: https://www.rebep.org.br/revista/article/view/269. Access in: 29 Mar. 2020.

PAIVA, V. L. M. O. A Linguagem dos Emojis. Trab. linguist. apl., Campinas, v. 55, n. 2, p. 379-401, 2016. https://doi.org/10.1590/010318134955176321. Available at:

http://www.scielo.br/scielo.php?script=sci_arttext\& pid=S0103-

18132016000200379\&lng=en\&nrm=iso. Access in: 24 Feb. 2020.

PARÁ (Estado) Secretaria de Saúde Pública. Coronavírus no Pará. Pará: SESPA, 2020. Available at: https://www.covid-19.pa.gov.br/\#/. Access in: 05 May 2020.

SARAIVA, J. Coronavírus: Itália ajuda pacientes a darem adeus às famílias. Metrópoles, 24/03/2020 9:58, atualizado 24/03/2020 10:41, 2020. Available at:

https://www.metropoles.com/saude/coronavirus-italia-ajuda-pacientes-terminais-a-daremadeus-as-familias. Access in: 02 Apr. 2020.

TEIXEIRA, A. T. J.; FROES, R. C.; ZAGO, E. C. A Comunicação e o Relacionamento da Família Atual em Virtude dos Novos Tempos. Revista Eletrônica de Comunicação, v. 1, n. 1, 2006. Available at: http://periodicos.unifacef.com.br/index.php/rec/article/view/422.

Access in: 10 Apr. 2020.

THE FAMILY DINNER PROJECT. 2020. Available at: https://thefamilydinnerproject.org/. Access in: 05 Apr. 2020.

TIC KIDS ONLINE BRASIL. Pesquisa sobre o uso da internet por crianças e adolescentes no Brasil: TIC kids online Brasil 2018. São Paulo: Comitê Gestor da Internet no Brasil, 2019. Available at:

https://cetic.br/media/docs/publicacoes/216370220191105/tic_kids_online_2018_livro_eletro nico.pdf. Access in: 17 Apr. 2020.

VILANOVA, R. Pacientes do Hospital Abelardo Santos já falam com familiares por videochamada. Governo do Pará: Secretaria de Saúde Pública, 2020. Available at: http://www.saude.pa.gov.br/2020/05/06/pacientes-do-hospital-abelardo-santos-ja-falam-comfamiliares-por-videochamada/. Access in: 06 Jun. 2020.

ZIEGLER, M. F. Coronavírus: estimativa aponta número de casos 14x maior do que o oficialSubnotificações dos Casos de Corona Vírus. Veja Saúde, atualizado em 18 ago 2020, 10 h46 Publicado em 8 Maio 2020, 12h18. Available at: https://saude.abril.com.br/medicina/coronavirus-estimativa-aponta-numero-de-casos-14xmaior-do-que-o- 